\title{
ОЙКОНІМИ НА *-ЬN ЗАХІДНОГО І СЕРЕДНЬОГО ПОЛІССЯ: АРЕАЛЬНИЙ І ХРОНОЛОГІЧНИЙ АСПЕКТИ
}

Купчинська 3. О. Ойконіми на *-ьn Західного і Середнього Полісся: ареальний і хронологічний аспекти.

У статті йдеться про ареальний і хронологічний виміри ойконімів на *-ьn Західного і Середнього Полісся. Просторово-часова характеристика географічних назв $\epsilon$ частиною їхньої стратиграфії. Акцентовано, що ойконіми на *-ьn генетично пов'язані з відносними прикметниками, після процесу субстантивації в 


\section{СТРУКТУРА I СЕМАНТИКА МОВНИХ ОДИНИЦЬ}

українській ойконімії зафіксовано великий пласт географічних назв із цим суфіксом. Західне і Середнє Полісся - це регіон України, який представляє великий інтерес для ономастів, бо ця територія репрезентує значний масив архаїчних ойконімів, зокрема географічних назв на *-ьn, $і \epsilon$ частиною загальноукраїнського і загальнослов' янського ареалів.

Ключові слова: стратиграфія, ареал, хронологія, архаїчний ойконім, ойконім на *-ьn.

Купчинская 3. О. Ойконимы на *-ьn Западного и Среднего Полесья: ареальный и хронологический аспекты.

В статье идет речь об ареальном и хронологическом измерении ойконимов на *-ьn Западного и Среднего Полесья. Пространственно-временная характеристика географических названий является частью их стратиграфии. Акцентируется внимание на том, что ойконимы на *-ьn генетически связаны с относительными прилагательными, после процесса субстантивации в украинской ойконимии зафиксировано большой пласт географических названий с этим суффиксом. Западное и Среднее Полесье - это регион Украины, представляющий большой интерес для ономастов, потому что эта территория репрезентирует значительный массив архаичных ойконимов, в частности географических названий *-ьn, и является частью всеукраинского и общеславянского ареалов.

Ключевые слова: стратиграфия, ареал, хронология, архаичный ойконим, ойконим на *-ьn.

Kupchynska Z. O. Oyconyms of West and Middle Polissia ending in *-sn: areal and chronological aspects.

The article is devoted to areal and chronological aspects of learning of oyconyms of West and Middle Polissia ending in *-ьn. Spatial and temporal characteristic of geographic names is a part of their stratigraphy. Stratigraphic method is used in complex formant studies of Slavonic oyconymy, because it provides localization of geographic names, finding out the chronology of toponyms and its quantitative characteristics. Areal studies of geographic names of this type in diachrony allow considering deeply oyconymic space, to characterize it, to determine its peculiarities in different historical periods and this leads to conclusions about the dynamics of onyms. Chronological aspect of studying of oyconymic types is to fix each onym from the first mention in historical documents to nowadays.

It is accented that oyconyms ending in *-ьn are genetically connected with relative adjectives and it is fixed a great part of geographic names with this suffix after the process of substantivation in Ukrainian oyconymy. Word-forming basis of these oyconyms are appellative relative adjectives ending in *-ьn which constantly form new onyms nowadays (in present days - microtoponyms). Relative adjectives are tightly connected with nouns; they evidently were one of the most archaic types and are not so 
widely represented in Ukrainian oyconymy because time partly removed them from the map. However cycle is inherent in "fashion". And that is why oyconyms with the suffix *-bn intensified again in XIX-XXI centuries. A lot of secondary names which were created indirectly arise in that period. Among oyconymic archaisms there are few names ending in *-bn; they are mainly creations of the newest epoch in Ukrainian history. Toponyms ending in *-bn are fixed on All-Slavonic territory and they are "viable" in toponymy nowadays. Mechanism of formation of oyconymy ending in *-ьn at the initial stage and in last centuries differs much: the first ones had a direct connection with a nature of geographic object; the second ones were formed according to appropriated formal scheme.

West and Middle Polissia is the region of Ukraine which is interesting for onomasts because this territory represents a significant massif of archaic oyconyms, and geographic names ending in *-bn in particular. These onyms are part of All-Ukrainian and All-Slavonic areas.

Key words: stratigraphy, area, chronology, archaic oyconym, oyconym ending in *-sn.

Ойконімні ареали та хронологію географічних назв розглядають у рамках стратиграфічних досліджень, які застосовують у мовознавстві відносно недавно. У праці «Stratygrafia toponimiczna» [8, с. 159]. С. Роспонд визначив поняття стратиграфії як «пошук структурно-топонімних нашарувань, залежних від часу і території». Цей метод опрацювання онімного матеріалу стає щораз популярнішим в українській ономастиці. Стратиграфічний метод використовувався в комплексних формантних дослідженнях української ойконімії, бо він передбачає локалізацію географічних назв, установлення хронології топонімів, кількісну характеристику. Починаючи 3 сімдесятих років XX ст., з'явилися праці, у яких висвітлюється стратиграфічний аспект українського ойконімікону $[1 ; 4 ; 2 ; 6 ; 7 ; 5]$. Просторово-часова характеристика ойконімного матеріалу супроводжується деякими об'єктивними труднощами, що пов'язані 3 фіксацією в історичних писемних пам'ятках географічних назв протягом десятьох століть, оскільки не на всіх часових зрізах і не на всій території України в однаковій мірі представлені історичні джерела, які репрезентували б онімний 
матеріал. Це зумовлює пряму залежність кількості виявлених назв від кількості пам'яток особливо на початковому етапі.

Онімний ареал - межі просторового онімного явища. Картографування географічних назв відповідного типу в діахронії дає змогу глибше розглянути ойконімний простір, охарактеризувати його, визначити особливості на різних історичних зрізах, а це сприяє появі висновків щодо динаміки онімів.

Хронологічний аспект вивчення ойконімних типів назв полягає у фіксації кожного оніма від першої згадки в історичних пам'ятках до сучасного етапу. У розвідці акцентуємо увагу лише на першофіксаціях. Географічні назви вибрано 3 історичних джерел, встановлено рік чи століття фіксації кожного ойконіма. Така хронологія відносна, бо спирається лише на фактаж пам'яток.

В основі назвотворення географічного об'єкта є переважно атрибут. Ойконіми на *-ьn генетично пов'язані 3 відносними прикметниками. Після процесу субстантивації в українській ойконімії зафіксовано великий пласт географічних назв із цим формантом. Проте зауважимо, що серед ойконімних архаїзмів залишилося їх не так багато, вони в основному - продукт найновішої доби в українській історії. Топоніми на *-ьn засвідчені на всій слов'янській території і $є$ досить «живучими» в топонімії. Словотвірною основою цих ойконімів $\epsilon$ апелятивні відносні прикметники на *-ьn, які постійно формують нові оніми і тепер (на сучасному етапі - мікротопоніми). Оскільки відносні прикметники найтісніше пов'язані з іменниками, то, очевидно, вони були одними 3 найдавніших типів i не так широко репрезентовані в українській ойконімії, бо час їх частково стер із нашої карти. Однак «моді» притаманна циклічність. Тому ойконіми із формантами *-ьn активізувалися знову в XIX-XXI ст. У цей період 3'являється велика кількість вторинних назв, що утворилися опосередковано, формально, тобто не так, як первинні, що безпосередньо характеризували поселення. «Формалізація» 
топонімної функції цього суфікса вплинула на продуктивність назв цього типу. Механізм формування ойконімів на *-ьn на початковому етапі і в останні сторіччя значно відрізняється: перші мали безпосередній зв'язок із характером географічного об'єкта, а другі - утворювалися за певною формальною схемою, явно віддаленою від його ознаки. Це чітко виявляється на прикладі ойконімів, що утворилися від назв істот: давні оніми (Журавно, Комарне, Рибно) були безпосередньо пов'язані із характеристикою об'єкта, їх перші фіксації сягають XV-XVI ст., а це ще $\epsilon$ додатковим аргументом на користь того, що апелятивний прикметник на *-ьn мав безпосередній зв'язок 3 онімом. Що стосується аналогічних назв, зафіксованих лише на сучасному етапі, то, вочевидь, ідеться про формальну схему номінації поселення [3, с. 33-63].

Західне і Середнє Полісся - це історико-етнографічний регіон, який цікавить дослідників різних галузей науки. Великий інтерес ця частина України представляє і для ономастів, адже саме на цій території зафіксовано значний масив архаїчних ойконімів, зокрема географічних назв на *-ьn. Це зумовлено не лише лінгвальними, але позалінгвальними чинниками, що заслуговує окремої розвідки.

До XIVст. Західне і Середнє Полісся репрезентоване назвами, розміщення яких збігається з північно-західними межами земель Галицько-Волинського князівства. Вони здебільшого збереглися досі: Березне (Хм., 1220) (у дужках зазначено локалізацію та першу фіксацію ойконіма), Дубно (Рв., 1100), Жадьнъ (Рв., Дубровицький, 1240), Кодня (Жт., 1301), Колодяжне (Жт., 1240), Коростень (Жт., 945), Котельня Нова (Жт., 1143), Красне (Рв., 1386), Курне (Жт., 1240), Облазьна (Жт., 1160), Полонне (Хм., 1061), Рівне (Рв., 1283), Теремне (Рв., 1322), Топільне (Вл., 1322), Чемерне (Рв., 1204).

У XV ст., порівняно 3 попередніми століттями, спостерігається загальне насичення i розростання обширу 
ойконімів на *-ьn. У Західному та Середньому Поліссі помітне на цей час навіть формування кількох осередків: 1) ВолодимирВолинський - Любомль - Камінь-Каширський; 2) Луцьк - Дубно Рівне; 3) Березне - Сарни; 4) смуга в таких координатах: Ізяслав Полонне - Житомир - Коростень. Загальна кількість назв у цьому сегменті ареалу представлена такими назвами: Березна (Рв., 1445), Березна Велика (Хм., 1470), Бытно (Ковель - Любитів, 1444), Вербичне (Вл., 1495), Глинне (Рв., 1499), Glinne (Турівський пов., 1451), Гніздичне (Тр., 1463), Гніздичне (Тр., 1463), Городнє (Вл., 1450), Grodno villa (Любомль, 1447), Dambno (Любомль, 1447), Derewnia (Дрогобич - Самбір, 1499), Дерно (Вл., 1445), Зимне (Вл., 1450), Ковно (Волинь, 1486), Когильне (Вл., 1449), Колодня (Рв., II пол. ХVст.), Колодне (Тр., 1463), Kołodnoje (Луцьк - Рівне, 1470), Коритне (Рв., 1472), Крошня (Жт., 1471), Лопушне (Тр., 1403), Метельне (Вл., 1433), Могильне (Жт., 1446), Нуйно (Вл., 1463), Папоротне (Др., 1444), Песочное (Мельницкая вол. - Ковельський пов., 1498), Ратне (Вл., 1433), Ratno (Холм, 1492), Родризна (Луцьк, 1452), Свинна (Ізяслав, 1420), Stalno (Холм, 1447), Ступно (Рв., 1428), Сушилно (Луцьк - Володимир - Ковель, 1444), Тинне (Рв., 1463), Урвенна (Рв., 1497), Яблунне (Рв., 1445).

Найбільше назв у XVI ст. зафіксовано в Західнополіській та Середньополіській частинах ареалу України: Баранне (Рв., 1589), Березне (Хм., 1583), Березно (Ратно, 1565), Боровне (Вл., 1545), Бронне (Рв., 1565), Велбошно (Острог, 1542), Вельбовна (Рв., 1534), Вербень (Рв., 1577), Wzlazno (Степань - Луцьк, 1577), Глезне (Жт., 1595), Гнойно (Вл., 1545), Головне (Вл., 1564), Голубне (Рв., 1595), Голузня (Волинь - Володимир, 1531), Грушевне (Вл., 1565), Деражне (Рв., 1577), Докшна (Луцьк - Жуків, 1587), Дошне (Вл., 1587), Дроздні (Вл., 1521), Дроздня (Волинь - Ковель - Голоблі, 1521), Дубечне (Вл., 1537), Дубна (Вл., 1545), Дубровно (Острог, II пол. XVI ст.), Жолобне (Жт., 1587), Жолобное (Луцьк - р. Стир, 1577), Źornowno (Волинь - Збараж, 1522), Журавно (Луцьк, 1594), Злазне (Рв., 1507), Зубильне (Вл., 1532), Iserna (Кременець - 
Маначин, 1583), Каменное (Рівне, 1545), Kamienne (Чорнобиль Овруч, 1545), Кобыльна (Староконстантинів - Кременець Ланівці, 1506), Колодежна (Вл., 1545), Колодяжне (Вл., 1537), Колонна (Володимир-Волинський, 1569), Korytna Wola (Острог, II пол. XVI ст.), Коритне (Хм., 1565), Kotelnia (Кременець, 1583), Krasna Wola (Ковель, 1543), Красне Велике (Луцьк, 1545), Красное (передмістя Луцька, 1508), Красное Село (Луцьк, 1563), Кримне (Вл., 1536), Krosnoje (Порицьк, 1583), Липне (Вл., 1577), Липне (Жт., кін. XVI ст.), Липне (Рв., 1577), Лишня (Рв., 1545), Лопушне (Тр., 1518), Михновное (дворище у Володимирському пов., 1502), Могильне (Вл., 1545), Морочне (Рв., 1511), Мошна (ВолодимирВолинський, 1564), Невольное (Луцьк, 1568), Овадне (Вл., 1545), Окольный городъ (Луцьк, 1504), Омельне (Вл., 1570), Підгородне (Вл., 1510), Підлужне (Рв., 1577), Пісочне (Вл., 1533), Плужне (Хм., 1542), Пнівне (Вл., 1564), Погрушовно (Луцьк, 1562), Полонне (Рв., 1561), Полонное Великое (Кременець, 1587), Полуничне (Рв., 1570), Попільня (Жт., XVI ст.), Постійне (Рв., 1537), Подтопольное (Рожища - Луцьк, 1585), Рівне (Вл., 1510), Рогізне (Рв., 1545), Рогозна (Берестечко - Луцьк - Дубно, 1545), Рокитне (Жт., 1545), Рокитне (Хм., 1570), Рудно (Житомир, XVI ст.), Сильне (Вл., 1546), Ситне (Рв., 1545), Сінне (Рв., 1535), Скородно (Овруч - Київ, 1545), Словечне (Жт., 1566), Сошичне (Вл., 1537), Сошне (Хм., 1534), Срібне (Рв., 1557), Стовпня (Жт., XVI ст.), Стольне (Холм, сер. XVI ст.), Трутня (Ратно, 1565), Холосне (Жт., XVI ст.), Холпня (Луцьк - Волинь, 1554), Чекно (Рв., 1564), Чернично (Рівне - Волинь, 1571), Шайно (Ковельський пов., 1538), Шибенне (Староконстантинів - Кременець, 1563), Шибенна (Київський пов. - Коростишів - Чорнобиль - p. Тетерів, 1593), Ягідне (Вл., 1568).

У цій частині земель України вимальовуються такі осередки:
1) Володимир-Волинський;
2) Любомль;
3) Ратне;
4) Ковель;
5) Луцьк; 6) Дубно; 7) Радивилів - Кременець; 8) Рівне - Острог;
9) Березне - Степань - Сарни - Зарічне; 10) басейн Норині і

๑) 3. О. Купчинська, 2018. 
Тетерева; 11) Житомир - Попільня - Брусилів.

У XVII ст. частина назв ареалу на *-ьn на Волині i Середньому Поліссі репрезентована ойконімами: Верхівня (Жт., 1600), Вуйна (Бердичів, 1662), Жеребная (Кременець Костянтинів, 1601), Завадно (Володимир, 1664), Кальне (Житомирський пов., 1633), Каменная Гора (Луцьк, 1655), Клітня (Жт., 1618), Красная (Луцьк, 1601), Кримне (Рв., 1629), Кропивня (Жт., 1650), Лішня (Тр., 1662), Лозичне (Хм., 1604), Лопушне (Хм., 1603), Могильня (Жт., 1647), Малинная (Базалія - Кременець, 1601), Мошна (Житомир - Чорнобиль, 1683), Немильня (Жт., 1609), Оранне (Радомишль - Овруч - Чорнобиль, 1683), Плесна (К-П, 1648), Подгородное (Володимир, 1650), Scieźarno (Овруч, 1687), Теремне (Вл., 1621), Тинне (Рв., 1681), Трипутня (Рв., 1654), Фосня Велика (Жт., 1682), Половне (Луцьк - Житомир, 1618), Radno (Овруч, 1683), Хворошня (Житомир, 1662), Хоровно (Володимир - Волинь, 1649), Черемошне (Вл., 1662), Черемошне (Жт., 1602), Шарне Старе (Жт., 1651), Ягідне (Кременецький пов., 1635), Ягідне (Чуднів, 1645), Хрубовная (Полонне, 1601).

Загальний розподіл назв відбувається в межах таких координат: 1) смуга: Радивилів - Кременець - Дубно - Луцьк Володимир-Волинський - Любомль - Ковель - Ратне - КаміньКаширський; 2) Ізяслав - Шепетівка - Полонне - Острог - Рівне; 3) Березне - Сарни - Дубровиця - Зарічне; 4) Любар - Чуднів Бердичів - Житомир; 5) Новоград-Волинський - Коростень Словечна - Овруч - Чорнобиль.

У XVIII ст. Поліський (Західний і Середній) сегмент ареалу представляють також чимало нових назв: Безпечна (Жт., 1765), Выгодная (Житомир - Краснополь, 1765), Вузня (Житомир, 1791), Гусинное (Волинь - Дубно, 1765), Дульное (Луцьк, 1765), Деражня Велика (Жт., 1765), Сльне (Рв., 1760), Жалобное (Берездів - Луцьк, 1765), Жульна (Березниця - Луцьк, 1765), Жульное (Степань, 1765), Зельна (Березниця - Луцьк, 1765), Зольня (Жт., 1780), Каменная (Березнів - Луцьк, 1765), Каменная Гута (Камінь- 
Каширський, 1765), Каменный Бродъ (Ловків - Житомир, 1765), Красное (Житомир, 1765), Красное (Клевань, 1765), Красное (Торговиця - Луцьк, 1765), Кропивна (Бердичів, 1765), Кропивная Буда (Коростишів - Житомир, 1765), Кропивня (Жт., ВолодарськоВолинський, 1765), Кропивня (Жт., Коростишівський, 1765), Кукільня (Жт., 1765), Ладна (Краснополь - Житомир, 1765), Ленчна (Луцьк, 1765), Лісна (Хм., 1765), Людная (Житомир, 1765), Мочульня (Жт., 1765), Нагірне (Рв., 1765), Нагорная (Овруцький у., 1765), Нагорное (Киселин - Володимир, 1765), Насльнная (Любар - Житомир, 1765), Озерне (Вл., 1765), Палухно (Горохів - Луцьк, 1765), Пас ъчна (Новоград-Волинський у., 1765), Перемильное (Звягель, 1765), Побойна (Житомир, 1765), Подлужно (Ровенський у., 1765), Подомна (Житомир, 1765), Полонное Новое (Кременець, 1765), Полонное Старое (Кременець, 1765), Полюхне (Вл., 1787), Расно (Житомирський у., 1765), Рибне (Острозький полк, 1775), Рожична (Хм., 1750), Рокитне (Рв., Костопільський, 1765), Рокитне (Рв., Рокитнівський, 1778), Рясне (Жт., 1771), Соломна (Рівне, 1765), Студенна (Ровно, 1765), Сумижна (Дубно, 1765), Трипольне (Луцьк - Рафалівка, 1765), Фосня Мала (Жт., 1778), Червонное (Житомирский, 1737), Яйно (Вл., 1775).

Вони розмістилися в таких координатах: 1) Кременець Радивилів; 2) Дубно - Луцьк - Володимир-Волинський; 3) Старокостянтинів - Ізяслав - Острог - Рівне; 4) Славута Полоне - Корець; 5) Ковель - Любомль - Шацьк - Ратне - КаміньКаширський; 6) Костопіль - Березне - Рокитне - Сарни Дубровиця; 7) Новоград-Волинський; 8) Любар - Бердичів Житомир; 9) Словечна - Овруч - Коростень - Іванків.

Західне і Середне Полісся у ХІХ ст. репрезентоване невеликою кількістю назв на *-ьn: Вільне (Рв., 1890), Гвіздярня (Жт., 1850), Деражня Середня (Жт., 1888), Кремне (Жт., 1865), Нивна (Жт., 1899), Омильне (Жт., 1800), Рокитне (Рв., 1888), Садибне (Жт., 1891), Ситне Мале (Рв., 1890), Топільня (Жт., 1870), Храбузна (Хм., 1860).

(с) 3. О. Купчинська, 2018. 
Середне Полісся поповнилося у $\mathrm{XX}$ ст. такими новозасвідченими назвами: Берное (Новоград-Волинський у., 1911), Богородичной церк. (Новоград-Волинський у., 1911), Бубно (Жт., 1911), Вересна (Жт., 1911), Вівня (Жт., 1946), Відерне (Жт., 1923), Гамарня (Жт., 1917), Гранітне (Жт., 1987), Гута-Осично (Житомирський у., 1911), Дружне (Жт., 1964), Залізня (Жт., 1946), Залужне (Жт., 1946), Колодне (Овруцький у., 1911), Клитня (Овруцький у., 1911), Колодежно (Новоград-Волинський у., 1911), Копельня (Жт., 1946), Красный Дворъ (Новоград-Волинський у., 1911), Кропивня (Жт., 1911), Кропивна (Житомирський у., 1911), Крошня Друга (Жт., 1946), Крошня Нова (Жт., 1946), Курное (Новоград-Волинський у., 1911), Лісна Колона (Жт., 1935), Лісна Рудня (Жт., 1920), Л ъсная (Овруцький у., 1911), Л ъсная-Слободка (Житомирський у., 1911), Лъсные (Житомирський у., 1911), Малая-Фосня (Овруцький у., 1911), Мирная (НовоградВолинський у., 1911), Мирне (Жт., Баранівський, 1946), Мирне (Жт., Червоноармійський, 1937), Молодіжне (Жт., 1989), Муравня (Жт., 1946), Осичне (Жт., 1946), Островъ-Стовпечно (Овруцький у., 1911), Папірня (Жт, 1922), Підгородне (Жт., 1947), Підлісне (Жт., 1971), Половинный (Овруцький у., 1911), Попільня (Жт., 1946), Пороховня (Житомирський у., 1911), Поташня (Жт., 1946), Прибережне (Жт., 1965), Пристанщійне (Жт., 1915), Радгоспне (Жт., 1925), Радгоспний (Жт., 1946), Рогізна (Жт., 1911), Ситне (Жт., 1962), Спірне (Жт., 1911), Стовпичне (Жт., 1946), Уиично (Житомирський у., 1911), Фосня Велика Друга (Жт., 1946), Чаплинное (Новоград-Волинський у., 1911), Червоногранітне (Жт., 1962), Червонопрапорне (Жт., 1962), Черемушное (Бердичів, 1917), Шарно Нове (Жт., 1911), Шитня (Новоград-Волинський у., 1911), Яблунне (Жт., 1911), Явне (Жт., 1911), Ямное (Овруцький у., 1911), Яструбна (Жт., 1917).

Вони досить рівномірно поширилися на території Житомирщини. Незначні скупчення спостерігаються в таких напрямах: 1) Коростень - Овруч; 2) Житомир - Новоград- 
Волинський.

На західній території Полісся в цей період сформувалися осередки навколо міст: Володимир-Волинський, Ковель, Любомль, Камінь-Каширський, Зарічне, Сарни, Костопіль, Рівне, Дубно, Кременець, Ізяслав, Полонне. Ця частина ареалу загалом рівномірно насичена назвами: Березна (Вл., 1946), БерезнаВеликая (Ізяславський у., 1911), Березне (Вл., 1946), Бронное (Ровенський у., 1911), Буйне (Рв., 1946), Вербичне Друге (Вл., 1946), Вербично (Ковельський у., 1911), Выгорное (Ізяславський у., 1911), Вижично (Вл., 1911), Выжично (Ковельський у., 1911), Височне (Вл., 1946), Височне (Вл., Ратнівський, 1946), В'язівне (Вл., 1946), Гірне (Вл., 1946), Гірне (Рв., Висоцький, 1946), Гірне (Рв., Володимирецький, 1946), Гірне (Рв., Рокитнянський, 1946), Гнійне (Рв., 1911), Голендерня (Володимир-Волинський у., 1911), Голубне (Рв., 1911), Горно (Вл., 1946), Гранична (Рв., 1946), Гранітне (Рв., 1986), Гранне (Рв., 1911), Грудня (Рв., 1946), Гурно (Луцький у., 1911), Дачне (Вл., 1964), Дашно (Ковельський у., 1911), Дерезне (Рв., 1946), Дидно (Ковельський у., 1911), Доленжно (ВолодимирВолинський у., 1911), Дохтирне (Вл., 1946), Дражно (Ровенський у., 1911), Дружне (Рв., 1963), Дубно (Рв., Рокитнівський, Глиннівська сільрада, 1906), Дубно (Рв., Рокитнянський, 1946), Завітне (Вл., 1964), Залізничне (Вл., 1946), Залужне (Вл., 1946), Заозерне (Вл., 1963), Запідне Друге (Вл., 1946), Запідне Перше (Вл., 1946), Зарічне (Рв., 1958), Заставне (Вл., 1946), Західний (Рв., 1946), Зубильно (Луцький у., 1911), Зульня (Рв., Дубровицький, 1911), Зульня (Рв., Степанський, 1911), Зурне (Рв., 1911), Исерна (Кременецький у., 1911), Караульна (Вл., 1946), Ковшинне (Рв., 1946), Колісня (Рв., 1946), Колодежное (Острозький у., 1911), Колодязне (Рв., 1946), Корытный Майданъ (Ізяславський у., 1911), Корінне (Рв., 1946), Костельний (Рв., 1946), Красильно (Дубенський у., 1911), Красне (Тр., 1946), Красно (Луцький у., 1911), Красное (Дубенський у., 1911), Кремінне (Рв., 1946), Кремінне (Рв., 1946), Крестельне (Рв., 1946), Кримне (Вл.,

๑) 3. О. Купчинська, 2018. 
Камінь-Каширський, 1911), Кримне (Вл., Шацький, 1946), Криничне (Вл., 1964), Кропивна (Хм., 1911), Кунечно (ВолодимирВолинський у., 1911), Кустарная (Острозький у., 1911), Ладна (Вл., 1946), Ледне (Рв., 1946), Ледно (Ровенський у, 1911), Липня (Рв., 1946), Лишня (Володимир-Волинський у., 1911), Лишня (Дубенський у., 1911), Лишня (Кременецький у., 1911), Лишня (Рв., 1946), Л всная (Острозький у., 1911), Лісне (Вл., 1946), Лішня Нова (Вл., 1946), Лішня Стара (Вл., 1946), Лубне (Рв., 1946), Лютечне (Вл., 1946), Лютне (Вл., 1911), Мирне (Вл., 1964), Мідний (Рв., 1946), Морочно Велике (Рв., 1946), Морочно Мале (Рв., 1946), Набережне (Рв., 1963), Надрічне (Вл., 1922), Невинне (Рв., 1946), Ново-Полонне (Полонський у., 1911), Омельное (Ровенський у., 1911), Остне (Рв., 1946), Островно (Володимир-Волинський у., 1911), Очеретне (Тр., 1946), Парня (Вл., 1946), Переможний (Вл., 1946), Пересічна (Рв., 1946), Песочная-Гута (Кременецький., 1911), Пильное (Кременецький у., 1911), Підгайне (Рв., 1946), Підлісне (Рв., 1960), Підлісне (Тр., 1946), Пірне (Рв., 1946), Пісочне (Вл., 1911), Пісочний (Вл., 1911), Плесная (Ізяславський у., 1911), Плотичне (Рв., 1946), Погородно (Володимир-Волинський у., 1911), Подвірний (Тр., 1946), Поддерно (Дубенський у., 1911), Полонное (Луцький у., 1911), Полуночне (Дубенський у., 1911), Полюхно (Володимир-Волинський у., 1911), Порохівня (Рв., 1946), Порохно (Вл., 1946), Потамарня (Володимир-Волинський у., 1911), Поташня (Рв., 1903), Привільне (Рв., 1963), Привітне (Рв., 1981), Прилісне (Вл., 1964), Пузня (Ровенський у., 1911), Пустельня (Кременецький у., 1911), Разд қльная (ВолодимирВолинський у., 1911), Ровно (Володимир-Волинський у., 1911), Рогізне (Вл., 1911), Рогозно (Володимир-Волинський у., 1911), Рогозно (Володимир-Волинський у., 1911), Рогозно (Ковельський у., 1911), Рудне (Вл., 1946), Свидно (Рв., 1946), Ситне (Луцький у., 1911), Скородне (Рв., 1946), Славне (Вл., 1964), Смольна (Вл., 1946), Спорно (Ковельський у., 1911), Степное (Острозький у., 1911), Студне (Рв., 1946), Стужно (Ровенський у., 1911), Суконне 
(Рв., 1946), Сильне (Вл., 1911), Татынное (Ровенський у., 1911), Теремно Новое (Луцький у., 1911), Теремно-Старое (Луцький у., 1911), Топульно (Луцький у., 1911), Тупальные высел. (Луцький у., 1911), Тупольно (Луцький у., 1911), Тупольно (Луцький у., 1911), Фишно (Луцький у., 1911), Хвойна (Вл., 1946), Хвойна Попова (Вл., 1946), Холодне (Тр., 1946), Цмовна (Ізяславський у., 1911), Чередне (Рв., 1946), Черемошне (Вл., 1946), Черемошно (ВолодимирВолинський у., 1911), Черепичная (Острозький у., 1911), Черничне (Вл., 1946), Четвертня (Вл., 1911), Шитня (Новоград-Волинський у., 1911), Шкільний (Рв., 1946), Яблонное (Ровенський у., 1911), Яблунне (Рв., 1946), Явно (Вл., 1946), Ягодно (ВолодимирВолинський у., 1911), Ягодно (Ковельський у., 1911), Ягодно (Ровенський у., 1911), Ямне (Вл., 1911), Ямне (Рв., Висоцький, 1946), Ямне (Рв., Рафалівський, 1946), Ямне (Рв., Рокитнянський, 1946), Ямни (Рв., 1946), Ямний (Рв., 1946).

Західнополіський та Середньополіський сегменти загальноукраїнського ареалу в XXI ст. малочисельні: Березна Воля (Вл., 2011), Деражня Велика (Жт., 2011), Дослідне (Жт., 2011), Заводне (Жт., 2011), Закомірня (Жт., 2011), Закриничне (Хм., 2011), Заможне (Жт., 2011), Запоківне (Вл., 2011), Зеленолужне (Вл., 2011), Зірне (Рв., 2011), Котельня Стара (Жт., 2011), Лобна (Вл., 2011), Мирне (Жт., 2011), Мирне (Рв., 2011), Мирне (Хм., 2011), Молодіжне (Рв., 2011), Озерне (Жт., Житомирський, 2011), Озерне (Жт., Любарський, 2011), Омельне (Вл., 2011), Підгірне (Вл., 2011), Під’язівні (Вл., 2011), Привітне (Вл., 2011), Привітне (Жт., 2011), Придорожне (Рв., 2011), Прикордонне (Рв., 2011), Радісне (Жт., 2011), Радужне (Рв., 2011), Різня (Жт., 2011), Роздольне (Жт., 2011), Сонячне (Жт., 2011), Станиійне (Жт., 2011), Черемошна Воля (Вл., 2011).

Ойконімія на *-ьn представлена на території Західного i Середнього Полісся досить широко, ця територія є частиною загальноукраїнського і загальнослов'янського ареалів. Твірними основами географічних назв на ${ }^{*}$-ьn були і $\epsilon$ відносні 
прикметники. Якісна різниця між ойконімами на *-ьn раннього та середнього періодів і XX-XXI ст. полягає в тому, що прикметники 3 цими суфіксами на початковому етапі формування назв на *-ьn засвідчували безпосередній зв'язок із характеристикою місцевості, однак поступово ойконіми почали утворюватися за аналогією. Таке масове явище спостерігаємо в XX-XXI ст. Інша причина надпродуктивності ойконімів на *-ьn у найпізніший період прикметники із цими суфіксами в останні два століття стрімко розвивалися, тому ця «активність» поширилася і на сферу онімів, порушуючи при цьому первинну мотивацію в процесі номінації географічного об’єкта.

\section{Література}

1. Бучко Д. Г. Українські топоніми на -івці, -инці : автореф. дис. ... канд. філол. наук : спец. 10.02.01 «Українська мова» / Д. Г. Бучко. - Львів, 1972. - 22 с.

2. Купчинська 3. О. Лексико-семантична i словотвірна структура географічних назв на -ин, -ів (територія України, X-XX ст.) : автореф. дис. ...канд. філол. наук : спец. 10.02.1 «Українська мова» / 3. О. Купчинська. - Львів, 1993. $-18 \mathrm{c}$.

3. Купчинська 3. О. Стратиграфія архаїчної ойконімії України : [монографія] / 3. О. Купчинська. - Львів : НТШ, 2016. - 1278 с.

4. Купчинський О. А. Найдавніші слов'янські топоніми України як джерело історико-географічних досліджень. Географічні назви на -ичі / О. А. Купчинський. - К. : Наукова думка, 1981. - 251 с.

5. Михайличенко Н. С. Структурно-семантичні типи українських ойконімів із формантами -ець, -иця : автореф. дис. ... канд. філол. наук : спец. 10.02.01 «Українська мова» / Н. Є. Михайличенко. - Львів, 2011. - 20 с.

6. Радьо Л. Н. Ойконіми України на *-јъ $\left(*_{-j a}\right.$ *-је) у X-XX ст. : автореф. дис. ... канд. філол. наук : спец. 10.02.01 «Українська мова» / Л. Н. Радьо. - ІваноФранківськ, 2004. - 18 с.

7. Царалунга І. Б. Українські топоніми на -ани(-яни) : автореф. дис. ... канд. філол. наук : спец. 10.02.01 «Українська мова» / І. Б. Царалунга. - Львів, 2006. $20 \mathrm{c}$.

8. Rospond S. Stratygrafia toponimiczna / S. Rospond // Z polskich studiów slawistycznych. - Warszawa, 1958. - S. 159-186.

Стаття надійшла до редакиії 15.01.2018 р. 